\title{
Challenges for Allogeneic Hematopoietic Stem Cell Transplantation in Chronic Myeloid Leukemia in the Era of Tyrosine Kinase Inhibitors
}

\author{
Anthony Oyekunle ${ }^{a, b}$ Evgeny Klyuchnikova Sunday Ocheni ${ }^{a, c}$ \\ Nicolaus Kröger ${ }^{a} \quad$ Axel R. Zander ${ }^{a} \quad$ Michele Baccarani $^{d} \quad$ Ulrike Bacher $^{a}$ \\ a Department for Stem Cell Transplantation, University Cancer Center Hamburg (UCCH), Hamburg, Germany; \\ ${ }^{b}$ Department of Hematology and Immunology, Obafemi Awolowo University (OAU), lle-Ife, ${ }^{C}$ Department of \\ Haematology and Immunology, University of Nigeria, Enugu Campus (UNEC), Nsukka, Nigeria; ${ }^{\mathrm{d}}$ Department of \\ Hematology-Oncology L. and A. Seràgnoli, S. Orsola-Malpighi Hospital, University of Bologna, Bologna, Italy
}

\section{Key Words}

Chronic myeloid leukemia • Tyrosine kinase inhibitors •

Allogeneic hematopoietic stem cell transplantation

\begin{abstract}
Following the introduction of the tyrosine kinase inhibitor (TKI) imatinib in the treatment of chronic myeloid leukemia (CML) patients, the allogeneic hematopoietic stem cell transplantation (HSCT) scene in CML has changed dramatically. The number of patients receiving HSCT in first chronic phase (CP) has declined rapidly, as allogeneic HSCT in CP is now performed in these patients only in case of failure or intolerance of TKIs. Second, those CML patients who undergo allogeneic HSCT represent a selection of high-risk patients due to more advanced disease with high rates of accelerated or blast phase (being associated with an increased relapse risk), advanced age and relevant co-morbidities. Efforts at meeting these special challenges are being developed: treatment with TKIs aims to improve the pre-transplant remission status before HSCT. Dose-reduced conditioning protocols were introduced to decrease transplant-related mortality in patients with co-morbidities or older age. In the post-transplant period, TKls may be administered for prophylaxis and
\end{abstract}

for treatment of post-transplant relapse. Still, the outcome of patients in advanced CML phases remains guarded, and requires an improvement in current transplant strategies.

Copyright $\odot 2011$ S. Karger AG, Basel

\section{Introduction}

The treatment of chronic myeloid leukemia (CML) underwent dramatic changes in recent years. From the 1980 s to 2000 , allogeneic hematopoietic stem cell transplantation (HSCT) was the treatment of choice for younger patients in first chronic phase (CP) if an HLA-matched donor was available. Before 1999, CML was the most frequent indication for allogeneic HSCT worldwide [1]. With the approval of imatinib by the FDA in 2001 [2], this tyrosine kinase inhibitor (TKI) soon became the frontline therapy for newly diagnosed CML patients. Following the International Randomized Study of Interferon and STI571 (IRIS) trial which clearly demonstrated the superiority of imatinib over a combination of IFN- $\alpha$ and cytarabine in patients with newly diagnosed CML in CP with respect to response rates and toxicity [3-6], transplantation rates in CML dropped quickly worldwide [7].

PD Dr. med. Ulrike Bacher, MD

Department for Stem Cell Transplantation, University Cancer Center Hamburg Martinistr. 52

DE-20246 Hamburg (Germany)

Tel.+49 4074105 4154, E-Mail u.bacher@uke.de 
As a result of the efficacy of imatinib, and thanks to the introduction of second-generation TKIs such as dasatinib and nilotinib, HSCT shifted from a preferred first-line therapy to a second, third or forth-line option, and is now reserved for patients with insufficient imatinib response, or with advanced phases of CML $[7,8]$. Pre-transplant application of first- or second-generation TKIs allowed patients with accelerated (AP) or blast phase (BP), who previously would not have survived long enough to benefit from transplantation, to become transplantation candidates $[7,9,10]$. Thus, as a result of the selection of patients with unfavorable risk profiles, increasing relapse rates in those patients with CML undergoing HSCT have been reported [11-13]. Intensive pretreatment, advanced age and co-morbidities are associated with an increased risk of transplant-related morbidity and mortality (TRM).

Thus, comprehensive approaches are needed for those CML patients being selected nowadays for HSCT to improve transplant outcomes. In the pre-transplant period, use of first- or second-generation TKIs has been shown to improve remission rates in patients with advanced disease $[14,15]$, either alone or in combination with cytotoxic agents [10, 16-18].

Some groups successfully introduced reduced-intensity conditioning (RIC) strategies in patients with CML who otherwise would not have been eligible for transplantation [19-22]. However, the number of RIC studies, specifically in CML, is still limited. With respect to the post-transplant period, imatinib has been explored for its potential for maintenance therapy or for therapy of CML relapse [21, 23-25]. Initial studies suggested acceptable tolerance also for second-generation TKIs in the posttransplant period [26]. Another option is the use of donor lymphocyte infusions (DLI) for adoptive immunotherapy [27-29], but its role should be reassessed in view of the new option of post-transplant TKI treatment. This review discusses recent changes in the indications and timing of HSCT in CML, and summarizes new options and developments of transplantation strategies while paying attention to the pre- and post-transplant periods in patients with CML.

\section{Actual Trends and Developments in HSCT}

Annual transplantation rates in first $\mathrm{CP}(\mathrm{CP} 1)$ dropped quickly after the first reports on the efficacy of imatinib in the year 2000 [30]. An EBMT study showed an increase from 559 HSCTs yearly for CML in 1991 to a maximum of 1,396 in 1999 , followed subsequently by a reduction to 802 in 2004 [31]. In 2007, there were a total of 434 HSCTs for CML, 228 in CP1 and 206 in advanced stages of the disease. The German Registry (DRST) reported a decrease in the annual transplantation rate in CML from a total of 357 in 1998 to 98 in 2004 (approx. a 73\% drop) [32]. At the same time, annual transplantation rates were increasing in other entities such as acute myeloid leukemia or myelodysplastic syndromes. However, the number of HSCTs for CML did not decline in all countries at the same rate [33].

\section{Shift of Stages in the Allogeneic Transplantation Setting}

Higher remission rates were reported due to the use of imatinib and second-generation TKIs in patients with advanced disease [7,9], leading to a shift in the stage at which CML patients were referred for HSCT. Thus, the proportion of patients with advanced disease ( $>\mathrm{CP} 1, \mathrm{AP}$, BP) increased from 32 to $53 \%$ of the annual transplantations in the DRST study [32]. Similarly, a large study of the Center of International Bone Marrow Transplantation Registry (CIBMTR) including 2,436 patients documented an increase in HSCTs for CP2 or AP from 24 to $41 \%$ of all transplantations for CML [30]. Here, two different mechanisms have to be assumed. First, the number of HSCTs in initial CML has undergone a more pronounced reduction when compared to those in advanced phase [15]. Second, remission rates could be improved in patients with advanced disease before HSCT. Thus, more patients in advanced disease became eligible for HSCT due to the use of first- or second-generation TKIs before transplant.

\section{Evolution of Prognostic Scoring Systems for HSCT in CML}

The first adequate scoring systems for evaluation of risks from Sokal et al. [34] included patient's age, spleen size, thrombocytes level and myeloblasts in peripheral blood as prognostic parameters. Hasford et al. [35] proposed that peripheral basophil and eosinophil counts had additional prognostic significance. With the development of HSCT, the classical stratification scales turned towards the incorporation of some transplant-related parameters such as donor type (related or unrelated), disease stage, donor/patient sex-compatibility, and intervals 
Table 1. Outcomes of chronic phase CML reported in 2009-2010

\begin{tabular}{|c|c|c|c|c|c|c|c|}
\hline \multirow[t]{2}{*}{ Study } & \multirow[t]{2}{*}{ Patients $^{1}$} & \multirow{2}{*}{$\begin{array}{l}\text { Disease } \\
\text { phase }\end{array}$} & \multirow{2}{*}{$\begin{array}{l}\text { Donor type/stem } \\
\text { cell source }\end{array}$} & \multirow[t]{2}{*}{ Conditioning } & \multicolumn{3}{|c|}{ Outcomes for CP patients } \\
\hline & & & & & OS & EFS/DFS & TRM/NRM \\
\hline $\begin{array}{l}\text { Shimoni } \\
\text { et al. }[17]^{2}\end{array}$ & $\begin{array}{l}21 \\
(45 \text { years, } 16-59)\end{array}$ & $\begin{array}{l}\mathrm{CP} 1=5 \\
\mathrm{Adv}=16\end{array}$ & $\begin{array}{l}\text { Sib 7, UR 13/ } \\
\text { PB 64, BM } 20\end{array}$ & $\begin{array}{l}\text { MAC 14, } \\
\text { RIC } 7\end{array}$ & $\begin{array}{l}64 \% \\
(2 \text { years })\end{array}$ & $\begin{array}{l}46 \% \\
\text { ( } 2 \text { years) }\end{array}$ & $\begin{array}{l}7 \% \\
(2 \text { years })\end{array}$ \\
\hline $\begin{array}{l}\text { Luo } \\
\text { et al. [57] }\end{array}$ & $\begin{array}{l}28 \\
(26 \text { years, } 17-49)\end{array}$ & $\mathrm{CP} 1=28$ & $\begin{array}{l}\text { Sib 13, UR 15/ } \\
\text { PB 21, BM } 7\end{array}$ & RIC 28 & $\begin{array}{l}81 \% \\
\text { (3 years) }\end{array}$ & $\begin{array}{l}67 \% \\
\text { (3 years) }\end{array}$ & $\begin{array}{l}15 \% \\
\text { (3 years) }\end{array}$ \\
\hline $\begin{array}{l}\text { Saussele } \\
\text { et al. [42] }\end{array}$ & $\begin{array}{l}84 \\
(37 \text { years, 16-62) }\end{array}$ & $\begin{array}{l}\mathrm{CP} 1=56 \\
\mathrm{Adv}=28\end{array}$ & $\begin{array}{l}\text { Sib 30, UR 54/ } \\
\text { PB 64, BM } 20\end{array}$ & $\begin{array}{l}\text { MAC 57, RIC 11, } \\
\text { others } 16\end{array}$ & $\begin{array}{l}91 \% \\
\text { (3 years) }\end{array}$ & $88 \% \mathrm{CMR}$ & $\begin{array}{l}8 \% \\
(3 \text { years })\end{array}$ \\
\hline $\begin{array}{l}\text { Copelan } \\
\text { et al. [47] }\end{array}$ & $\begin{array}{l}335 \\
(37 \text { years, } 18-58)\end{array}$ & $\begin{array}{l}\mathrm{CP}=229 \\
\mathrm{Adv}=106\end{array}$ & $\begin{array}{l}\text { Sib 335/ } \\
\text { BM } 335\end{array}$ & MAC 335 & $\begin{array}{l}71 \% \\
(3 \text { years })\end{array}$ & $\begin{array}{l}69 \% \\
\text { (3 years) }\end{array}$ & $\begin{array}{l}14 \% \\
\text { (3 years) }\end{array}$ \\
\hline $\begin{array}{l}\text { Bacher } \\
\text { et al. [32] }\end{array}$ & $\begin{array}{l}1,716 \\
(40 \text { years, } 1-68)\end{array}$ & $\begin{array}{l}\mathrm{CP} 1=1,084 \\
\mathrm{Adv}=542\end{array}$ & $\begin{array}{l}\text { Rel 773, UR 932/ } \\
\text { PB 1,069, BM } 640\end{array}$ & $\begin{array}{l}\text { MAC } 724 \text {, RIC 147, } \\
\text { others } 800\end{array}$ & $\begin{array}{l}70 \% \\
\text { (5 years) }\end{array}$ & $\begin{array}{l}41 \% \\
\text { (5 years) }\end{array}$ & $\begin{array}{l}28 \% \\
\text { (5 years) }\end{array}$ \\
\hline
\end{tabular}

OS = Overall survival; EFS/DFS = event-/disease-free survival; TRM/NRM = transplant-related/non-relapse mortality; CP1 = first chronic phase: $\mathrm{Adv}=$ advanced $(>\mathrm{CP} 1 />\mathrm{CP})$; $\mathrm{Sib}=$ sibling; Rel = related; $\mathrm{UR}=$ unrelated; $\mathrm{PB}=$ peripheral blood; $\mathrm{BM}=$ bone $\mathrm{marrow}$; $\mathrm{MAC}=$ myeloablative conditioning; $\mathrm{RIC}=$ reduced-intensity conditioning; $\mathrm{CMR}=$ complete molecular remission.

${ }^{1}$ Figures in parentheses are median age and range. ${ }^{2}$ This study includes $2 \mathrm{Ph}+\mathrm{ALL}$ patients.

between diagnosis and transplant (more or less than 12 months). This has eventually led to the Gratwohl score [36]. Moreover, some additional elements known to influence TRM (captured in an HSCT co-morbidity score) have been shown to be helpful $[37,38]$. Additionally, novel prognostically relevant markers have been suggested. For instance, increased expression of the polycomb group gene $B M I-1$ (the gene is essential for the maintenance of the stem cell pool and enhances self-renewal of human stem and progenitor cells) was shown to be associated with lower TRM in patients with CML [39]. Likewise, the possession of one (C1 or C2) KIR2DS5 (natural killer immunoglobulin-like receptor) ligand, as opposed to both, has been shown to be associated with improved leukemia-free survival after HSCT [40].

\section{Indications for HSCT in CML}

Allogeneic HSCT remains a confirmed curative approach for CML patients, but is associated with a significant TRM risk. Nevertheless, due to improvements of supportive care and HLA typing methods, the results of HSCT have been substantially improved over the time, especially for those patients with unrelated donors.

According to the updated guidelines of the European LeukemiaNet (ELN) [41], indications for HSCT in CML are: at diagnosis for patients presenting in $\mathrm{AP}$ or $\mathrm{BP}$ after TKI pre-treatment, at imatinib failure for patients progressing to AP or BP (after second-generation TKI pretreatment) or with the T315I mutation, or for all patients failing second-generation TKI treatment. These categories are clearly defined by hematological, cy togenetic and molecular criteria: failure of imatinib means failure to achieve complete hematological remission (CHR) at 3 months, or failure to achieve any cytogenetic response at 6 months. Also, persistence of $\geq 35 \% \mathrm{Ph}+$ metaphases at 12 months, or less than complete cytogenetic response (CCR) at 18 months is defined as imatinib failure. Resistance is defined as loss of CHR or CCR; or development of highly resistant $\mathrm{ABL}$ kinase domain mutations during imatinib treatment [41].

Saussele et al. [42] published the results of an interim analysis of a large randomized study (German CML study IV) including 1,242 CML patients, which was very instructive regarding the current role of allogeneic HSCT. A total of 84 patients underwent allogeneic HSCT, 56 of them in CP (19 in early CP and 37 after imatinib failure). The 3 -year overall survival (OS) probability of the patients in CP was $91 \%$. Interestingly, in matched pair analysis, the 3-year disease OS of 53 patients who underwent transplantation was not different from that of 106 matched patients who did not (92 vs. 96\%). Saussele et al. [42] concluded that allogeneic HSCT 
might become the preferred second-line approach in case of imatinib failure for suitable patients in $\mathrm{CP}$, with a donor. However, considering the relatively young age of the patients reported (median age of 36 years) this assertion deserves further investigation by additional randomized studies.

\section{Advanced CML}

According to the ELN recommendations, allogeneic HSCT is indicated for all patients in AP or BP as first- or second-line option. In both cases, it is recommended that HSCT should be preceded by TKIs; for first-line, highdose imatinib (600 or $800 \mathrm{mg}$ ), and for second-line, second-generation TKIs (dasatinib or nilotinib) [41]. In the study from Saussele et al. [42], a total of 28 patients in advanced disease received allogeneic HSCT following pretransplant application of TKIs. Following HSCT, these patients experienced a 3-year OS of 59\% (CI: 39-76\%). Therefore, Saussele et al. [42] agreed with earlier suggestions that the best long-term survival results in blast phase are achieved by allogeneic HSCT and that most long-term survivors in blast phase have received an allogeneic HSCT, mostly in CP2.

\section{Recent Results of HSCT in CML}

From 1980 to 1990, more than 2,600 allogeneic HSCT were performed in CML patients in Europe. The probability of survival at 20 years after stem cell transplantation was about 40,20 and $10 \%$ for patients in CP1, AP and $\mathrm{BP}$, respectively $[43,44]$. Subsequently, better supportive care, risk stratification strategies and better HLA typing methods allowed a reduction of TRM from 41 to $8 \%$ for all transplanted patients with CML. Nevertheless, the risks, especially for older patients, still remain high [42, 44].

Recent HSCT data showed the following results for patients with CML: EBMT data from 2000 to 2003 reported 2-year OS rates of $74 \%$ for sibling and $63 \%$ for unrelated allogeneic HSCT in patients in CP1 [44]. The CIBMTR documented survival rates of 79 and $72 \%$ at 1 and 2 years, respectively, for the transplant period 1999 to 2004 for patients in all phases of CML [45]. The German CML Study III documented 5 -year survival rates of $72 \%$ in lowrisk, $62 \%$ in intermediate-risk, and $49 \%$ in high-risk patients [46]. Recently published results of the German CML study IV showed remarkable improvements of al- logeneic HSCT, with the 3-year OS of patients in first CP being higher than $90 \%$ in spite of the fact that the majority of these patients underwent transplantation with an EBMT score equal to or higher than 3 [42].

\section{Myeloablative Conditioning}

Copelan et al. [47] reported on myeloablative conditioning with busulfan/cyclophosphamide (BuCy) in 335 CML patients (CP, $n=229$; $>C P, n=106)$ who underwent allogeneic HSCT from HLA-matched related donors from 1984 to 1995, with >14 years median follow-up. The estimated probability of 18-year leukemia-free survival was 56 and $11 \%$ for $\mathrm{CP}$ and $>\mathrm{CP}$ patients, respectively. Late relapses $(\mathrm{p}=0.039)$ and late nonrelapse mortality (NRM, $\mathrm{p}=0.008$ ) occurred at higher rates in patients beyond $\mathrm{CP}$ at transplantation. Occasional relapses were seen as late as 18 years after HSCT [47].

In an attempt to minimize regimen-related toxicity while preserving antileukemic effects in myeloablative conditioning, Radich et al. [48] used an intravenous BuCy preparative regimen with busulfan dose targeted to achieve a steady-state plasma concentration of $\geq 900 \mathrm{ng} /$ $\mathrm{ml}$. This strategy was based on reports of lower relapse and better survival rates when serum levels of busulfan were $\geq 917 \mathrm{ng} / \mathrm{l}$ [49]. This approach resulted in an estimated 3-year OS and a disease-free survival (DFS) of 86 and $78 \%$, respectively, and low relapse and NRM rates of 8 and $14 \%$, respectively, were reported.

\section{Reduced Intensity Conditioning}

In view of the modified selection criteria for HSCT with the afore-mentioned shift to poor-risk patients and patients having experienced more intensive pretreatment, RIC was introduced in CML [50-52]. In the study by Kerbauy et al. [53], low-dose TBI (2 Gy) with or without fludarabine $\left(90 \mathrm{mg} / \mathrm{m}^{2}\right)$ was used in $24 \mathrm{CML}$ patients in $\mathrm{CP} 1 / 2$ or $\mathrm{AP}$ who were ineligible for myeloablative conditioning (MAC). A 3-year OS rate of 54\% was obtained. The 2-year survival estimates obtained for patients in $\mathrm{CP} 1$ and $>\mathrm{CP} 1$ were 70 and 56\%, respectively, with an NRM of $21 \%$. It thus appears that this RIC strategy is promising for such patients. Faber et al. [54] compared the results of RIC- and MAC-HSCT in 55 CML patients. Median OS was better in the RIC than the MAC cohort ( 26 vs. 9 months; $\mathrm{p}=0.036$ ) even though the relapse rate was significantly higher in the RIC patients (45 vs. $0 \%$ ). 
In one large EBMT study by Crawley et al. [20], outcomes of 186 patients with CML at a median age of 50 years predominantly in CP (63\% of patients) and receiving RICHSCT, were analyzed. The regimen consisted of busulfan (cumulative, $\leq 8 \mathrm{mg} / \mathrm{kg}$ ) and TBI ( $\leq 6 \mathrm{~Gy}$ ). The 2-year NRM was $23 \%$, while the 3 -year OS and relapse-free survival were 58 and $37 \%$, respectively. A complete molecular response (CMR) was achieved in $40 \%$ of patients, and CCR in $62 \%[20,55]$. Overall response rates were affected by the stages of disease, being $>90$ and $67 \%$ in $\mathrm{CP}$ and $\mathrm{AP}$, respectively, but only $22 \%$ in $\mathrm{BP}$. Also, the risk of relapse was $>65 \%$ in patients in $\mathrm{AP} / \mathrm{BP}$, compared to $35 \%$ in those in CP1. Thus, advanced disease remains poorly controlled with current RIC regimens, while outcomes seem favorable for CP patients.

A combination of treosulfan $\left(3 \times 14 \mathrm{~g} / \mathrm{m}^{2}\right)$ and fludarabine $\left(5 \times 30 \mathrm{mg} / \mathrm{m}^{2}\right)$ used by Holowiecki et al. [56] resulted in OS, DFS and NRM (at 2 years) of 85,82 and $15 \%$, respectively. Or et al. [51] explored the role of DLIs following RIC-HSCT (using fludarabine, low-dose busulfan and ATG) in 24 adult and pediatric patients in CP1. Six patients experienced mixed chimerism. Withdrawal of post-transplant immunosuppression with cyclosporin A resulted in molecular remission in 3 of the 6 patients. The remaining 3 patients received DLIs as post-transplant adoptive strategy and achieved complete donor chimerism [51].

Regarding the use of RIC-HSCT in younger patients, Luo et al. [57] reported on $28 \mathrm{CP1}$ CML patients (median age 26 years) who received busulfan $(8 \mathrm{mg} / \mathrm{kg}$ per os or equivalent intravenously), fludarabine $\left(150 \mathrm{mg} / \mathrm{m}^{2}\right)$ and ATG $(20 \mathrm{mg} / \mathrm{kg})$. Twenty-five patients received grafts from HLA-matched, 3 patients from HLA-mismatched donors. Although all patients had received pre-transplant imatinib therapy (and were resistant to imatinib), the 3 -year estimated OS and DFS were 81 and 67\%, respectively. Following HSCT, 91\% of patients achieved a molecular remission, but there was a high relapse rate of $32 \%$. Early and cumulative 3 -year TRM were 3.6 and $15.4 \%$, respectively [57].

\section{The Use of TKIs before Allogeneic HSCT}

\section{Tolerance of Pre-Transplant Imatinib}

Several studies explored the application of pre-HSCT imatinib (at doses of 400-600 $\mathrm{mg} /$ day) in patients who were later referred to HSCT $[14,58]$. In the study by Zaucha et al. [58], the median time of imatinib administration before HSCT was 8 months, but some patients re- ceived imatinib pre-transplant for more than 2 years. Others confirmed that pre-transplant imatinib did not increase the toxicity of subsequent allogeneic HSCT [59, 60]. Neutrophil and thrombocyte engraftment were not affected. Thus, pre-transplant application of imatinib does not appear to increase the toxicity of subsequent conditioning and has no influence on engraftment.

Contrarily, discussions have developed around the suspected immunosuppressive effects of imatinib. Oehler et al. [60] evaluated outcomes for 145 patients (CP $50 \%$, AP $41 \%$, BP 9\%) who received pre-transplant imatinib at a median dose of $500 \mathrm{mg}$ and 231 patients (CP $79 \%$, AP $17 \%$, BP 4\%) who did not. The authors found that the risk to develop extensive chronic graft-versushost disease (cGvHD) post-transplant was significantly lower in patients who received imatinib compared with those who did not $(p<0.001)$, while that of acute GvHD (aGvHD) was similar [60]. Other investigators showed efficacy of the compound in the treatment of refractory cGvHD associated with fibrotic features [61, 62]. Imatinib has been shown to inhibit $\mathrm{T}$ cell proliferation and activation as well as $\mathrm{T}$ cell responses to herpes viruses [63]. Other reports indicate that imatinib may be immunosuppressive by inhibiting dendritic cell development and function, or T cell responses [64]. However, it is unclear how long these effects might persist after imatinib is stopped, and whether pre-transplant imatinib might have such prolonged effects in the post-transplant period.

\section{Efficacy of Pre-Transplant Imatinib}

A recent CIBMTR study by Lee et al. [45] in 1,309 CML patients $(\mathrm{CP} 1, \mathrm{n}=860 ;>\mathrm{CP}, \mathrm{n}=449)$ showed $\mathrm{a}$ trend for improved OS rates for patients in CP1 who received imatinib before HSCT. The OS estimates for patients in CP1 who received imatinib and those who did not were 79 vs. $74 \%$ at 1 year $(p=0.08)$ and 72 vs. $65 \%$ at 3 years $(\mathrm{p}=0.07)$, respectively. In contrast, in patients with advanced CML, post-transplant survival did not differ significantly, whether patients received imatinib prior to HSCT or not: adjusted OS for imatinib and nonimatinib patients were both $48 \%$ at 1 year and 36 vs. $34 \%$ at 3 years, respectively [45]. Others found no difference in outcomes between the imatinib-treated and historical cohorts. For instance, Oehler et al. [60] reported a 3 -year OS in CP and AP/CP2 patients of 74 and 54\%, respectively, in the imatinib-treated patients, which was very similar to 78 and $48 \%$, respectively, in the nonimatinib patients. 


\section{Combination Therapies before HSCT}

The use of imatinib in combination with other medications or novel agents in the pre-transplant period is another interesting approach in patients with advanced disease. Fruehauf et al. [16] studied 16 patients with CML-BP who received a combination of mitoxantrone/etoposide and imatinib. This combination was tolerated and was claimed to result in a more effective reduction of the leukemia cell load and to improve the outcome after HSCT. $\mathrm{CHR}$ resulted from the combination of imatinib with mitoxantrone/etoposide in $81 \%$ of patients [16]. In the MD Anderson study, imatinib was combined with low-dose cytarabine and idarubicin in patients in BP. A second CP or CHR was achieved in $74 \%$ of the patients, and HSCT was then possible in $32 \%$ of cases [18]. Deenik et al. [65] assessed the efficacy and tolerance of escalated imatinib in combination with 2 cycles of intravenous cytarabine $\left(200 \mathrm{mg} / \mathrm{m}^{2}\right.$ or $1 \mathrm{~g} / \mathrm{m}^{2}$ on days $\left.1-7\right)$ in 162 CML patients, the majority of whom had low/intermediate Sokal or Euro risk scores. They observed the 5-year cumulative incidences of a complete cytogenetic, major molecular and complete molecular response in 89,71 and $53 \%$ of patients, respectively. Importantly, a higher Sokal risk score was inversely associated with CCR (hazard ratio of $0.63 ; \mathrm{p}<0.001)$. A higher dose of imatinib and a higher dose of cytarabine were associated with increased complete molecular response. OS and progression-free survival at 5 years were 96 and $92 \%$, respectively [65].

\section{Management of Post-Transplant Relapse of CML}

\section{Minimal Residual Disease Monitoring in the \\ Post-Transplant Period}

Considering the increased risk of relapse in patients with advanced disease and, eventually, RIC-HSCT, measurement of the minimal residual disease (MRD) load has become particularly important following HSCT. Several authors [66-68] have demonstrated that the kinetics of $B C R-A B L 1$ expression levels in transplanted CML patients was prognostically relevant. Lange et al. [68] showed that slow reduction of the $B C R-A B L 1$ expression levels early after transplantation (days +28 and +56 ) was predictive for an increased relapse rate. A total of 19 CML patients were evaluated $(\mathrm{CP} 1, \mathrm{n}=9 ;>\mathrm{CP} 1, \mathrm{n}=5 ; \mathrm{AP}, \mathrm{n}=4$; $\mathrm{BP}, \mathrm{n}=1$ ) who underwent RIC-HSCT. Eleven had positive $B C R-A B L 1$ levels $(<0.01 \%, \mathrm{n}=4 ;>0.01 \%, \mathrm{n}=7)$. Five patients (1 with $B C R-A B L 1$ expression of $<0.01 \%$ and 4 with expression of $>0.01 \%$ ) experienced hematological relapse within a median of 1 month (range 1-6 months) from the first positive $B C R-A B L 1$ expression level post-transplant. Asnafi et al. [66] evaluated the prognostic importance of the MRD levels in $38 \mathrm{CML}$ patients $(\mathrm{CP}, \mathrm{n}=34, \mathrm{AP}, \mathrm{n}=$ 4). Patients who experienced increased $B C R-A B L 1$ expression levels $\left(\geq 10^{-4}\right)$ experienced higher relapse rates when compared to those with MRD levels $<10^{-4}$ on day 100 after HSCT (79 vs. $29 \%, \mathrm{p}=0.009$ ).

\section{TKI-based Post-Transplant Strategies}

Before the introduction of TKIs, adoptive immunotherapy with DLIs was the most frequently used therapeutic strategy in CML patients with post-transplant relapse [69-72]. Following the introduction of TKIs, the role of DLI therapy needs to be reviewed. In a recent study, Carpenter et al. [23] performed prophylactic administration of imatinib after HSCT in $\mathrm{Ph}+$ leukemias. In that study, 22 patients with $B C R-A B L 1$-positive ALL and 7 with high-risk CML were recruited and given imatinib from the time of engraftment until 1 year after HSCT. They observed a 2 -year relapse rate of $18 \%$. The authors concluded that the use of post-transplant imatinib with DLIs might prevent relapse through synergistic immunological effects.

Olavarria et al. [73] reported on the outcomes for 22 CML patients in CP, in whom imatinib $300 \mathrm{mg}$ daily was given from day +35 up to 12 months from RIC-HSCT. Twenty-one patients completed 11 months of imatinib, all remaining in remission. After the discontinuation of imatinib, 15 patients (71\%) experienced molecular relapse at a median of 17 months (range 13-29 months) post-transplant and were treated with DLIs. With a median follow-up of 36 months (range 12-64 months), 19 patients were alive (OS 87\%). Fifteen (68\%) have achieved molecular remission. Thus, post-transplant imatinib can be used to manipulate the kinetics of CML relapse after RIC-HSCT and reduce the risk of early relapse [73].

In the study by DeAngelo et al. [24], 15 CML patients in $C P(n=10)$ or advanced phases $(n=5)$ with post-transplant relapse were treated with imatinib $(400-600 \mathrm{mg}$ daily). At 6 months from the beginning of the treatment of the patients in CP relapse, CMR $(n=7)$ or at least CCR $(n=2)$ were achieved in 9 of the 10 CP patients, but only one of the 5 patients in advanced phase achieved CCR. Imatinib was well tolerated in all patients. Responses in patients relapsed in CP were rapid, durable and associated with conversion to full donor chimerism without GvHD [24]. 
Kantarjian et al. [25] reported an overall response rate of $79 \%$ in 28 adults with CML (CP, $\mathrm{n}=5 ; \mathrm{AP}, \mathrm{n}=15$; and $\mathrm{BP}, \mathrm{n}=8)$ who received imatinib (400-1,000 mg daily) due to post-transplant relapse. Nineteen of the patients (68\%) were alive after a median follow-up of 15 months, 9 in CCR. Therefore, imatinib seemed to effectively control CML recurring after HSCT.

Recently, Wright et al. [74] reviewed 22 patients (8 in $\mathrm{CP}$ and 14 advanced) treated for post-HSCT CML relapse with TKIs (imatinib, $\mathrm{n}=20$, and/or dasatinib, $\mathrm{n}=6$ ). They observed that 14 patients (64\%) achieved CMR, 8 of whom had advanced disease. The authors concluded that TKI therapy is capable of inducing durable molecular responses for CML relapsing after HSCT, both in chronic and advanced phases.

Although few studies still have examined the role of second-generation TKIs (dasatinib or nilotinib) in the management of CML relapse post-transplant, current guidelines recommend escalating the dose of imatinib or switching to new TKIs in CML patients with relapse or resistance [75]. Data on the use of second generation TKIs in the post-transplant period [26] are still limited.

\section{Conclusion}

Due to the new selection criteria for allogeneic HSCT in patients with CML, more patients with co-morbidities and at later phases of disease are being transplanted, resulting in a higher risk of post-transplant relapse $[11,13$, 12] and a higher risk for TRM during allogeneic HSCT. Therefore, novel strategies have to be developed for patients with CML undergoing HSCT. Diverse studies dem- onstrated that pre-transplant therapy with imatinib has no negative effects on subsequent transplantation $[14,45$, $58,59]$. Second-generation TKIs such as dasatinib or nilotinib have also successfully been used in advanced phases of CML before HSCT [8]. Other promising modification strategies for patients in advanced disease include the addition of imatinib to diverse combination chemotherapy regimens, for example mitoxantrone/etoposide pre-transplant [16], or combinations with lowdose cytarabine and idarubicin in patients with blast phase [18]. Additionally, various RIC regimens are being tried, for instance based on low-dose TBI with or without fludarabine $[53,76]$. With these protocols, patients in CP who are not eligible for MAC-HSCT seem to have acceptable outcomes, while those in advanced disease seem to do less well. The use of DLI in the post-transplant period after RIC-HSCT might need to be further investigated [51].

In patients with post-transplant relapse, imatinib can as well be successfully used with acceptable tolerance [23]. However, it should be noted that many patients undergoing allogeneic HSCT have a history of imatinib resistance. Therefore, studies on larger cohorts regarding the use of second-generation TKIs in the post-transplant period are needed [26]. However, despite these combined approaches to improve pre- and post-transplant therapy, and to develop less toxic conditioning regimens, prognosis of patients in advanced CML remains guarded. Therefore, despite the low numbers of patients with CML undergoing allogeneic HSCT nowadays, efforts should continue to develop new transplant strategies aiming at improving the safety and the chance of cure for these patients with CML.

\section{References}

1 Gratwohl A, Baldomero H, Passweg J, Frassoni F, Niederwieser D, Schmitz N, UrbanoIspizua A: Hematopoietic stem cell transplantation for hematological malignancies in Europe. Leukemia 2003;17:941-959.

-2 Druker BJ, Talpaz M, Resta DJ, Peng B, Buchdunger E, Ford JM, Lydon NB, Kantarjian H, Capdeville R, Ohno-Jones S, Sawyers CL: Efficacy and safety of a specific inhibitor of the BCR-ABL tyrosine kinase in chronic myeloid leukemia. N Engl J Med 2001;344: 1031-1037.

-3 Druker BJ, Guilhot F, O’Brien SG, Gathmann I, Kantarjian H, Gattermann N, Deininger MW, Silver RT, Goldman JM, Stone RM, Cervantes F, Hochhaus A, Powell BL, Gabrilove JL, Rousselot P, Reiffers J, Cor- nelissen JJ, Hughes T, Agis H, Fischer T, Verhoef G, Shepherd J, Saglio G, Gratwohl A, Nielsen JL, Radich JP, Simonsson B, Taylor K, Baccarani M, So C, Letvak L, Larson RA: Five-year follow-up of patients receiving imatinib for chronic myeloid leukemia. N Engl J Med 2006;355:2408-2417.

-4 Hahn EA, Glendenning GA, Sorensen MV, Hudgens SA, Druker BJ, Guilhot F, Larson RA, O’Brien SG, Dobrez DG, Hensley ML, Cella D: Quality of life in patients with newly diagnosed chronic phase chronic myeloid leukemia on imatinib versus interferon alfa plus low-dose cytarabine: results from the IRIS Study. J Clin Oncol 2003;21:2138-2146.

$\checkmark 5$ Hughes TP, Kaeda J, Branford S, Rudzki Z, Hochhaus A, Hensley ML, Gathmann I,
Bolton AE, van Hoomissen I, Goldman JM, Radich JP: Frequency of major molecular responses to imatinib or interferon alfa plus cytarabine in newly diagnosed chronic myeloid leukemia. N Engl J Med 2003;349: 1423-1432.

-6 O’Brien SG, Guilhot F, Larson RA, Gathmann I, Baccarani M, Cervantes F, Cornelissen JJ, Fischer T, Hochhaus A, Hughes T, Lechner K, Nielsen JL, Rousselot P, Reiffers J, Saglio G, Shepherd J, Simonsson B, Gratwohl A, Goldman JM, Kantarjian H, Taylor K, Verhoef G, Bolton AE, Capdeville R, Druker BJ: Imatinib compared with interferon and low-dose cytarabine for newly diagnosed chronic-phase chronic myeloid leukemia. N Engl J Med 2003;348:994-1004. 
7 Baccarani M, Saglio G, Goldman J, Hochhaus A, Simonsson B, Appelbaum F, Apperley J, Cervantes F, Cortes J, Deininger M, Gratwohl A, Guilhot F, Horowitz M, Hughes T, Kantarjian H, Larson R, Niederwieser D, Silver R, Hehlmann R: Evolving concepts in the management of chronic myeloid leukemia: recommendations from an expert panel on behalf of the European LeukemiaNet. Blood 2006;108:1809-1820.

-8 Jabbour E, Cortes JE, Giles FJ, O’Brien S, Kantarjian HM: Current and emerging treatment options in chronic myeloid leukemia. Cancer 2007;109:2171-2181.

-9 Bornhäuser M, Kröger N, Schwerdtfeger R, Schafer-Eckart K, Sayer HG, Scheid C, Stelljes M, Kienast J, Mundhenk P, Fruehauf S, Kiehl MG, Wandt H, Theuser C, Ehninger G, Zander AR: Allogeneic haematopoietic cell transplantation for chronic myelogenous leukaemia in the era of imatinib: a retrospective multicentre study. Eur J Haematol 2006; 76:9-17.

10 Menzel H, von Bubnoff N, Hochhaus A, Haferlach C, Peschel C, Duyster J: Successful allogeneic stem cell transplantation in second chronic-phase CML induced by the tyrosine kinase inhibitor nilotinib (AMN107) after blast crisis under imatinib. Bone Marrow Transplant 2007;40:83-84.

11 Hansen JA, Gooley TA, Martin PJ, Appelbaum F, Chauncey TR, Clift RA, Petersdorf EW, Radich J, Sanders JE, Storb RF, Sullivan KM, Anasetti C: Bone marrow transplants from unrelated donors for patients with chronic myeloid leukemia. N Engl J Med 1998;338:962-968.

12 Martin MG, Uy GL, Procknow E, StockerlGoldstein K, Cashen A, Westervelt P, Abboud CN, Augustin K, Luo J, Dipersio JF, Vij R: Allo-SCT conditioning for myelodysplastic syndrome and acute myeloid leukemia with clofarabine, cytarabine and ATG. Bone Marrow Transplant 2009;44:13-17.

13 McGlave PB, Shu XO, Wen W, Anasetti C, Nademanee A, Champlin R, Antin JH, Kernan NA, King R, Weisdorf DJ: Unrelated donor marrow transplantation for chronic myelogenous leukemia: 9 years' experience of the national marrow donor program. Blood 2000;95:2219-2225.

14 Kim DW, Chung YJ, Lee S, Kim YJ, Chung NG, Kim JA, Oh IH, Kim TG, Kim YL, Goh HG, Kim SH, Cho B, Kim HJ, Min CK, Lee JW, Jin JY, Han CW, Kim JW, Min WS, Kim HK, Kim CC, Kim HJ: Pretransplant imatinib can improve the outcome of nonmyeloablative stem cell transplantation without increasing the morbidity in Philadelphia chromosome-positive chronic myeloid leukemia. Leukemia 2004;18:1907-1909.

15 Myojo T, Hino N: Complete remission from chronic myelogenous leukemia-blastic crisis caused by reduced intensity stem cell transplantation following partial remission due to imatinib. Intern Med 2004;43:126-130.
16 Fruehauf S, Topaly J, Buss EC, Fischer T, Ottmann OG, Emmerich B, Müller MC, Schuld P, Balleisen L, Hehlmann R, Ho AD, Hochhaus A: Imatinib combined with mitoxantrone/etoposide and cytarabine is an effective induction therapy for patients with chronic myeloid leukemia in myeloid blast crisis. Cancer 2007;109:1543-1549.

-17 Shimoni A, Leiba M, Schleuning M, Martineau G, Renaud M, Koren-Michowitz M, Ribakovski E, le Coutre P, Arnold R, Guilhot F, Nagler A: Prior treatment with the tyrosine kinase inhibitors dasatinib and nilotinib allows stem cell transplantation (SCT) in a less advanced disease phase and does not increase SCT Toxicity in patients with chronic myelogenous leukemia and philadelphia positive acute lymphoblastic leukemia. Leukemia 2009;23:190-194.

18 Quintas-Cardama A, Kantarjian H, GarciaManero G, O’Brien S, Faderl S, Ravandi F, Giles F, Thomas D, Wierda W, Cortes J: A pilot study of imatinib, low-dose cytarabine and idarubicin for patients with chronic myeloid leukemia in myeloid blast phase. Leuk Lymphoma 2007;48:283-289.

19 Champlin R, Khouri I, Shimoni A, Gajewski J, Kornblau S, Molldrem J, Ueno N, Giralt S, Anderlini P: Harnessing graft-versus-malignancy: non-myeloablative preparative regimens for allogeneic haematopoietic transplantation, an evolving strategy for adoptive immunotherapy. Br J Haematol 2000;111: $18-29$.

20 Crawley C, Szydlo R, Lalancette M, Bacigalupo A, Lange A, Brune M, Juliusson G, Nagler A, Gratwohl A, Passweg J, Komarnicki M, Vitek A, Mayer J, Zander A, Sierra J, Rambaldi A, Ringden O, Niederwieser D, Apperley JF: Outcomes of reduced-intensity transplantation for chronic myeloid leukemia: an analysis of prognostic factors from the Chronic Leukemia Working Party of the EBMT. Blood 2005;106:2969-2976.

21 Kebriaei P, Detry MA, Giralt S, Carrasco-Yalan A, Anagnostopoulos A, Couriel D, Khouri IF, Anderlini P, Hosing C, Alousi A, Champlin RE, De Lima M: Long-term follow-up of allogeneic hematopoietic stem-cell transplantation with reduced-intensity conditioning for patients with chronic myeloid leukemia. Blood 2007;110:3456-3462.

22 Maziarz RT: Who with chronic myelogenous leukemia to transplant in the era of tyrosine kinase inhibitors? Curr Opin Hematol 2008; 15:127-133.

-23 Carpenter PA, Snyder DS, Flowers ME, Sanders JE, Gooley TA, Martin PJ, Appelbaum FR, Radich JP: Prophylactic administration of imatinib after hematopoietic cell transplantation for high-risk Philadelphia chromosome-positive leukemia. Blood 2007; 109:2791-2793.
24 DeAngelo DJ, Hochberg EP, Alyea EP, Longtine J, Lee S, Galinsky I, Parekkedon B, Ritz J, Antin JH, Stone RM, Soiffer RJ: Extended follow-up of patients treated with imatinib mesylate (gleevec) for chronic myelogenous leukemia relapse after allogeneic transplantation: durable cytogenetic remission and conversion to complete donor chimerism without graft-versus-host disease. Clin Cancer Res 2004;10:5065-5071.

25 Kantarjian HM, O’Brien S, Cortes JE, Giralt SA, Rios MB, Shan J, Giles FJ, Thomas DA, Faderl S, De Lima M, Garcia-Manero G, Champlin R, Arlinghaus R, Talpaz M: Imatinib mesylate therapy for relapse after allogeneic stem cell transplantation for chronic myelogenous leukemia. Blood 2002;100: 1590-1595.

26 Klyuchnikov E, Schafhausen P, Kröger N, Brümmendorf TH, Osanmaz O, Asenova S, Zabelina T, Ocheni S, Ayuk F, Zander AR, Bacher U: Second-generation tyrosine kinase inhibitors in the post-transplant period in patients with chronic myeloid leukemia or Philadelphia-positive acute lymphoblastic leukemia. Acta Haematol 2009;122:6-10.

27 Kolb HJ, Mittermüller J, Clemm C, Holler E, Ledderose G, Brehm G, Heim M, Wilmanns W: Donor leukocyte transfusions for treatment of recurrent chronic myelogenous leukemia in marrow transplant patients. Blood 1990;76:2462-2465.

28 Mackinnon S, Papadopoulos EB, Carabasi MH, Reich L, Collins NH, Boulad F, CastroMalaspina H, Childs BH, Gillio AP, Kernan NA: Adoptive immunotherapy evaluating escalating doses of donor leukocytes for relapse of chronic myeloid leukemia after bone marrow transplantation: separation of graftversus-leukemia responses from graft-versus-host disease. Blood 1995;86:1261-1268.

29 Vela-Ojeda J, Garcia-Ruiz Esparza MA, Reyes-Maldonado E, Jimenez-Zamudio L, Moreno-Lafont M, Garcia-Latorre E, Ramirez-Sanjuan E, Montiel-Cervantes L, Tripp-Villanueva F, Garcia-Leon LD, ValaSanchez M, Rosas-Cabral A, Vina-Zubieta JA, Galindo-Rodriguez G, Vadillo-Buenfil M, Salazar-Exaire D: Donor lymphocyte infusions for relapse of chronic myeloid leukemia after allogeneic stem cell transplantation: prognostic significance of the dose of $\mathrm{CD} 3(+)$ and $\mathrm{CD} 4(+)$ lymphocytes. Ann Hematol 2004;83:295-301.

30 Giralt SA, Arora M, Goldman JM, Lee SJ, Maziarz RT, McCarthy PL, Sobocinski KA, Horowitz MM: Impact of imatinib therapy on the use of allogeneic haematopoietic progenitor cell transplantation for the treatment of chronic myeloid leukaemia. Br J Haematol 2007;137:461-467.

- 31 Gratwohl A, Baldomero H, Frauendorfer K, Urbano-Ispizua A: EBMT activity survey 2004 and changes in disease indication over the past 15 years. Bone Marrow Transplant 2006;37:1069-1085. 
32 Bacher U, Klyuchnikov E, Zabelina T, Ottinger $\mathrm{H}$, Beelen DW, Schrezenmeier $\mathrm{H}$, Ehninger G, Müller C, Berger J, Suttorp M, Kolb HJ, Kröger N, Zander AR: The changing scene of allogeneic stem cell transplantation for chronic myeloid leukemia - a report from the German Registry covering the period from 1998 to 2004. Ann Hematol 2009; 88:1237-1247.

- 33 Gratwohl A, Baldomero H, Schwendener A, Rocha V, Apperley J, Frauendorfer K, Niederwieser D: The EBMT activity survey 2007 with focus on allogeneic HSCT for AML and novel cellular therapies. Bone Marrow Transplant 2009;43:275-291.

- 34 Sokal JE, Cox EB, Baccarani M, Tura S, Gomez GA, Robertson JE, Tso CY, Braun TJ, Clarkson BD, Cervantes F: Prognostic discrimination in 'good-risk' chronic granulocytic leukemia. Blood 1984;63:789-799.

- 35 Hasford J, Pfirrmann M, Hehlmann R, Allan NC, Baccarani M, Kluin-Nelemans JC, Alimena G, Steegmann JL, Ansari H: A new prognostic score for survival of patients with chronic myeloid leukemia treated with interferon alfa. Writing Committee for the Collaborative CML Prognostic Factors Project Group. J Natl Cancer Inst 1998;90:850-858.

-36 Gratwohl A, Hermans J, Goldman JM, Arcese W, Carreras E, Devergie A, Frassoni F, Gahrton G, Kolb HJ, Niederwieser D, Ruutu T, Vernant JP, de Witte T, Apperley J: Risk assessment for patients with chronic myeloid leukaemia before allogeneic blood or marrow transplantation. Chronic Leukemia Working Party of the European Group for Blood and Marrow Transplantation. Lancet 1998;352:1087-1092.

- 37 Pavlu J, Kew AK, Taylor-Roberts B, Auner HW, Marin D, Olavarria E, Kanfer EJ, MacDonald DH, Milojkovic D, Rahemtulla A, Rezvani K, Goldman JM, Apperley JF, Szydlo RM: Optimizing patient selection for myeloablative allogeneic hematopoietic cell transplantation in chronic myeloid leukemia in chronic phase. Blood 2010;115:40184020.

- 38 Sorror ML, Maris MB, Storb R, Baron F, Sandmaier BM, Maloney DG, Storer B: Hematopoietic cell transplantation (HCT)-specific comorbidity index: a new tool for risk assessment before allogeneic HCT. Blood 2005;106:2912-2919.

-39 Mohty M, Szydlo RM, Yong AS, Apperley JF, Goldman JM, Melo JV: Association between BMI-1 expression, acute graft-versus-host disease, and outcome following allogeneic stem cell transplantation from HLA-identical siblings in chronic myeloid leukemia. Blood 2008;112:2163-2166.
40 van der Meer A, Schaap NP, Schattenberg AV, van Cranenbroek B, Tijssen HJ, Joosten I: KIR2DS5 is associated with leukemia free survival after HLA identical stem cell transplantation in chronic myeloid leukemia patients. Mol Immunol 2008;45:3631-3638.

41 Baccarani M, Cortes J, Pane F, Niederwieser D, Saglio G, Apperley J, Cervantes F, Deininger M, Gratwohl A, Guilhot F, Hochhaus A, Horowitz M, Hughes T, Kantarjian H, Larson R, Radich J, Simonsson B, Silver RT, Goldman J, Hehlmann R: Chronic myeloid leukemia: an update of concepts and management recommendations of European LeukemiaNet. J Clin Oncol 2009;27:6041-6051.

42 Saussele S, Lauseker M, Gratwohl A, Beelen DW, Bunjes D, Schwerdtfeger R, Kolb HJ, Ho AD, Falge C, Holler E, Schlimok G, Zander AR, Arnold R, Kanz L, Dengler R, Haferlach C, Schlegelberger B, Pfirrmann M, Müller MC, Schnittger S, Leitner A, Pletsch N, Hochhaus A, Hasford J, Hehlmann R: Allogeneic hematopoietic stem cell transplantation (allo SCT) for chronic myeloid leukemia in the imatinib era: evaluation of its impact within a subgroup of the randomized German CML Study IV. Blood 2010;115:1880-1885.

43 Gratwohl A, Heim D: Current role of stem cell transplantation in chronic myeloid leukaemia. Best Pract Res Clin Haematol 2009; 22:431-443.

44 Gratwohl A, Brand R, Apperley J, Crawley C, Ruutu T, Corradini P, Carreras E, Devergie A, Guglielmi C, Kolb HJ, Niederwieser D: Allogeneic hematopoietic stem cell transplantation for chronic myeloid leukemia in Europe 2006:transplant activity, long-term data and current results. An analysis by the Chronic Leukemia Working Party of the European Group for Blood and Marrow Transplantation (EBMT). Haematologica 2006;91: 513-521.

45 Lee SJ, Kukreja M, Wang T, Giralt SA, Szer J, Arora M, Woolfrey AE, Cervantes F, Champlin RE, Gale RP, Halter J, Keating A, Marks DI, McCarthy PL, Olavarria E, Stadtmauer EA, Abecasis M, Gupta V, Khoury HJ, George B, Hale GA, Liesveld JL, Rizzieri DA, Antin JH, Bolwell BJ, Carabasi MH, Copelan E, Ilhan O, Litzow MR, Schouten HC, Zander AR, Horowitz MM, Maziarz RT: Impact of prior imatinib mesylate on the outcome of hematopoietic cell transplantation for chronic myeloid leukemia. Blood 2008;112: 3500-3507.

46 Hehlmann R, Berger U, Pfirrmann M, Heimpel H, Hochhaus A, Hasford J, Kolb HJ, Lahaye T, Maywald O, Reiter A, Hossfeld DK, Huber C, Löffler H, Pralle H, Queisser W, Tobler A, Nerl C, Solenthaler M, Goebeler ME, Griesshammer M, Fischer T, Kremers S, Eimermacher H, Pfreundschuh $M$, Hirschmann WD, Lechner K, Wassmann B, Falge C, Kirchner HH, Gratwohl A: Drug treatment is superior to allografting as firstline therapy in chronic myeloid leukemia. Blood 2007;109:4686-4692.
47 Copelan EA, Crilley PA, Szer J, Dodds AJ, Stevenson D, Phillips G, Elder P, NivisonSmith I, Avalos BR, Penza S, Topolsky D, Sobecks R, Kalaycio M, Bolwell BJ: Late mortality and relapse following BuCy2 and HLAidentical sibling marrow transplantation for chronic myelogenous leukemia. Biol Blood Marrow Transplant 2009;15:851-855.

48 Radich JP, Gooley T, Bensinger W, Chauncey T, Clift R, Flowers M, Martin P, Slattery J, Sultan D, Appelbaum FR: HLA-matched related hematopoietic cell transplantation for chronic-phase CML using a targeted busulfan and cyclophosphamide preparative regimen. Blood 2003;102:31-35.

49 Slattery JT, Sanders JE, Buckner CD, Schaffer RL, Lambert KW, Langer FP, Anasetti C, Bensinger WI, Fisher LD, Appelbaum FR: Graft-rejection and toxicity following bone marrow transplantation in relation to busulfan pharmacokinetics. Bone Marrow Transplant 1995;16:31-42.

-50 Bornhäuser M, Kiehl M, Siegert W, Schetelig J, Hertenstein B, Martin H, Schwerdtfeger R, Sayer HG, Runde V, Kröger N, Theuser C, Ehninger G: Dose-reduced conditioning for allografting in 44 patients with chronic myeloid leukaemia: a retrospective analysis. $\mathrm{Br}$ J Haematol 2001;115:119-124.

51 Or R, Shapira MY, Resnick I, Amar A, Ackerstein A, Samuel S, Aker M, Naparstek E, Nagler A, Slavin S: Nonmyeloablative allogeneic stem cell transplantation for the treatment of chronic myeloid leukemia in first chronic phase. Blood 2003;101:441-445.

52 Baron F, Storb R: Current roles for allogeneic hematopoietic cell transplantation following nonmyeloablative or reduced-intensity conditioning. Clin Adv Hematol Oncol 2005;3:799-819.

-53 Kerbauy FR, Storb R, Hegenbart U, Gooley T, Shizuru J, Al-Ali HK, Radich JP, Maloney DG, Agura E, Bruno B, Epner EM, Chauncey TR, Blume KG, Niederwieser D, Sandmaier BM: Hematopoietic cell transplantation from HLA-identical sibling donors after low-dose radiation-based conditioning for treatment of CML. Leukemia 2005;19:990997.

-54 Faber E, Koza V, Vitek A, Mayer J, Sedlacek P, Zak P, Zapletalova J, Benesova K, Krejcova H, Steinerova K, Maresova I, Cetkovsky P: Reduced-intensity conditioning for allogeneic stem cell transplantation in patients with chronic myeloid leukemia is associated with better overall survival but inferior disease-free survival when compared with myeloablative conditioning - a retrospective study of the Czech National Hematopoietic Stem Cell Transplantation Registry. Neoplasma 2007;54:443-446. 
-55 Scott BL, Sandmaier BM, Storer B, Maris MB, Sorror ML, Maloney DG, Chauncey TR, Storb R, Deeg HJ: Myeloablative vs nonmyeloablative allogeneic transplantation for patients with myelodysplastic syndrome or acute myelogenous leukemia with multilineage dysplasia: a retrospective analysis. Leukemia 2006;20:128-135.

56 Holowiecki J, Giebel S, Wojnar J, KrawczykKulis M, Markiewicz M, Holowiecka-Goral A, Freund M, Casper J: Treosulfan and fludarabine low-toxicity conditioning for allogeneic haematopoietic stem cell transplantation in chronic myeloid leukaemia. Br J Haematol 2008;142:284-292.

-57 Luo Y, Lai XY, Tan YM, Shi JM, Zhao YM, Han XY, Zheng GF, Zhu XL, Sun J, Zheng YL, Wu GQ, He JS, Chen SY, Jin AY, Xie WZ, Ye XJ, Cai Z, Lin MF, Huang H: Reducedintensity allogeneic transplantation combined with imatinib mesylate for chronic myeloid leukemia in first chronic phase. Leukemia 2009;23:1171-1174.

-58 Zaucha JM, Prejzner W, Giebel S, Gooley TA, Szatkowski D, Kalwak K, Wojnar J, Kruzel T, Balon J, Holowiecki J, Hellmann A: Imatinib therapy prior to myeloablative allogeneic stem cell transplantation. Bone Marrow Transplant 2005;36:417-424.

59 Perz JB, Khorashad JS, Marin D, Apperley JF, Olavarria E: Imatinib preceding allogeneic stem cell transplantation in chronic myeloid leukemia. Haematologica 2006;91:11451146.

60 Oehler VG, Gooley T, Snyder DS, Johnston L, Lin A, Cummings CC, Chu S, Bhatia R, Forman SJ, Negrin RS, Appelbaum FR, Radich JP: The effects of imatinib mesylate treatment before allogeneic transplantation for chronic myeloid leukemia. Blood 2007;109: 1782-1789.

-61 Magro L, Mohty M, Catteau B, Coiteux V, Chevallier P, Terriou L, Jouet JP, YakoubAgha I: Imatinib mesylate as salvage therapy for refractory sclerotic chronic graft-versushost disease. Blood 2009;114:719-722.

62 Olivieri A, Locatelli F, Zecca M, Sanna A, Cimminiello M, Raimondi R, Gini G, Mordini N, Balduzzi A, Leoni P, Gabrielli A, Bacigalupo A: Imatinib for refractory chronic graft-versus-host disease with fibrotic features. Blood 2009;114:709-718.
63 Seggewiss R, Lore K, Greiner E, Magnusson MK, Price DA, Douek DC, Dunbar CE, Wiestner A: Imatinib inhibits T-cell receptormediated T-cell proliferation and activation in a dose-dependent manner. Blood 2005; 105:2473-2479.

64 Appel S, Balabanov S, Brümmendorf TH, Brossart P: Effects of imatinib on normal hematopoiesis and immune activation. Stem Cells 2005;23:1082-1088.

65 Deenik W, Janssen JJWM, van der Holt B, Verhoef GEG, Smit WM, Kersten MJ, Daenen SMGJ, Verdonck LF, Ferrant A, Schattenberg AVMB, Sonneveld P, van Marwijk Kooy M, Wittebol S, Willemze R, Wijermans PW, Beverloo HB, Löwenberg B, Valk PJM, Ossenkoppele GJ, Cornelissen JJ: Efficacy of escalated imatinib combined with cytarabine in newly diagnosed patients with chronic myeloid leukemia. Haematologica 2010;95: 914-921.

66 Asnafi V, Rubio MT, Delabesse E, Villar E, Davi F, Damaj G, Hirsch I, Dhedin N, Vernant JP, Varet B, Buzyn A, Macintyre E: Prediction of relapse by day 100 BCR-ABL quantification after allogeneic stem cell transplantation for chronic myeloid leukemia. Leukemia 2006;20:793-799.

67 Ballestrero A, Cirmena G, Dominietto A, Garuti A, Rocco I, Cea M, Moran E, Nencioni A, Miglino M, Raiola AM, Bacigalupo A, Patrone F: Peripheral blood vs. bone marrow for molecular monitoring of BCR-ABL1 levels in chronic myelogenous leukemia, a retrospective analysis in allogeneic bone marrow recipients. Int J Lab Hematol 2010 32:387-391.

68 Lange T, Deininger M, Brand R, Hegenbart U, Al-Ali H, Krahl R, Poenisch W, Uharek L, Leiblein S, Gentilini C, Petersdorf E, Storb RF, Niederwieser D: BCR-ABL transcripts are early predictors for hematological relapse in chronic myeloid leukemia after hematopoietic cell transplantation with reduced intensity conditioning. Leukemia 2004; 18 : 1468-1475.

69 Kolb HJ, Mittermüller J, Clemm C, Holler E, Ledderose G, Brehm G, Heim M, Wilmanns W: Donor leukocyte transfusions for treatment of recurrent chronic myelogenous leukemia in marrow transplant patients. Blood 1990;76:2462-2465.

70 Kolb HJ, Schattenberg A, Goldman JM, Hertenstein B, Jacobsen N, Arcese W, Ljungman P, Ferrant A, Verdonck L, Niederwieser $\mathrm{D}$, van Rhee F, Mittermüller J, de Witte T, Holler E, Ansari H: Graft-versus-leukemia effect of donor lymphocyte transfusions in marrow grafted patients. Blood 1995;86: 2041-2050.
71 Porter DL, Roth MS, McGarigle C, Ferrara $\mathrm{JL}$, Antin JH: Induction of graft-versus-host disease as immunotherapy for relapsed chronic myeloid leukemia. N Engl J Med 1994;330:100-106.

72 Giralt S, Hester J, Huh Y, Hirsch-Ginsberg C, Rondon G, Seong D, Lee M, Gajewski J, Van Besien K, Khouri I, Mehra R, Przepiorka D, Korbling M, Talpaz M, Kantarjian H, Fischer H, Deisseroth A, Champlin R: CD8-depleted donor lymphocyte infusion as treatment for relapsed chronic myelogenous leukemia after allogeneic bone marrow transplantation. Blood 1995;86:4337-4343.

73 Olavarria E, Siddique S, Griffiths MJ, Avery S, Byrne JL, Piper KP, Lennard AL, Pallan L, Arrazi JM, Perz JB, O'Shea D, Goldman JM, Apperley JF, Craddock CF: Posttransplantation imatinib as a strategy to postpone the requirement for immunotherapy in patients undergoing reduced-intensity allografts for chronic myeloid leukemia. Blood 2007;110: 4614-4617.

74 Matthew PW, John DS, Michael JB, Stephen HN, Heather JS, Cynthia LT, Donna E. Hogge, Thomas JN, Kevin WS, Yasser RAM, Sujaatha N, Maryse MP, Clayton AS, Donna LF. Response to Tyrosine Kinase Inhibitor Therapy in Patients with Chronic Myelogenous Leukemia Relapsing in Chronic and Advanced Phase Following Allogeneic Hematopoietic Stem Cell Transplantation. Biology of blood and marrow transplantation 2010;16: 639-646.

75 Cortes J, Kim DW, Raffoux E, Martinelli G, Ritchie E, Roy L, Coutre S, Corm S, Hamerschlak N, Tang JL, Hochhaus A, Khoury HJ, Brümmendorf TH, Michallet M, Rege-Cambrin G, Gambacorti-Passerini C, Radich JP, Ernst T, Zhu C, Van Tornout JM, Talpaz M: Efficacy and safety of dasatinib in imatinibresistant or -intolerant patients with chronic myeloid leukemia in blast phase. Leukemia 2008;22:2176-2183.

76 Scott BL, Sandmaier BM, Storer B, Maris MB, Sorror ML, Maloney DG, Chauncey TR, Storb R, Deeg HJ: Myeloablative vs nonmyeloablative allogeneic transplantation for patients with myelodysplastic syndrome or acute myelogenous leukemia with multilineage dysplasia: a retrospective analysis. Leukemia 2006;20:128-135. 